\title{
Radiofrequency ablation versus percutaneous ethanol injection for hepatocellular carcinoma: a meta-analysis of randomized controlled trials
}

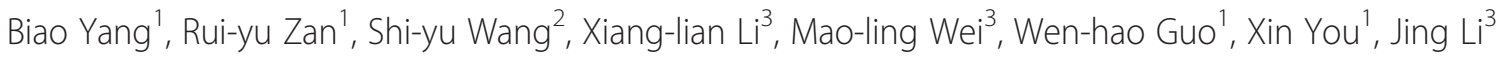 \\ and Zheng-yin Liao ${ }^{1 *}$
}

\begin{abstract}
Background: Radiofrequency ablation (RFA) and percutaneous ethanol injection (PEI) are treatment methods for patients with early-stage hepatocellular carcinoma (HCC) who are not suitable for surgery. Although some reports indicate that RFA is better than PEI, results from previous reviews and analyses are inconsistent. Therefore, this meta-analysis was performed to more thoroughly evaluate the effects of these treatments in patients with HCC.

Methods: A literature search was conducted using the Excerpta Medica dataBASE, PubMed, the Cochrane Library, the American Society of Clinical Oncology database, the China National Knowledge Infrastructure database, the Wanfang database, the Chinese Biomedical Literature Database, and the Chongqing VIP database without language limitations. The primary outcome evaluated was overall survival, and secondary outcomes included complete response and local recurrence. Comparisons were made between Asian and European studies.

Results: Total pooled and subgroup analyses of Asian studies that included selection biases revealed that RFA is superior to PEI with respect to overall survival (hazard ratio (HR), 0.54; $95 \%$ confidence interval $(\mathrm{Cl}), 0.37$ to $0.80 ; P<0.01$ ) and complete response (relative risk (RR), 1.10; $95 \% \mathrm{Cl} 1.03$ to 1.18; $P<0.01$ ). However, no significant difference was observed between RFA and PEI in the European studies. In Asian studies, RFA was associated with a lower local recurrence rate than $\mathrm{PEl}$ at 1 year (RR, $0.44 ; 95 \% \mathrm{Cl} 0.20$ to $0.95 ; P<0.05)$ and 3 years $(\mathrm{RR}, 0.35 ; 95 \% \mathrm{Cl} 0.22$ to $0.55 ; P<0.01)$. However, local recurrence was significantly lower after only 3 years in European studies (RR, 0.50; $95 \% \mathrm{Cl} 0.32$ to $0.78 ; P<0.05)$.

Conclusions: RFA was only superior to PEI in Asian studies that included selection bias. Thus, there is insufficient evidence to support the idea that RFA is superior to PEl for patients with cirrhotic HCC. Additional large-scale, multicenter, randomized controlled trials that control for selection bias are needed to fully elucidate the optimal treatment method for HCC.
\end{abstract}

Keywords: Hepatocellular carcinoma, Radiofrequency ablation, Ethanol injection, Meta-analysis

\section{Background}

Hepatocellular carcinoma (HCC) is the sixth most common cancer and the third most frequent cause of cancerrelated deaths worldwide [1]. HCC is a global problem, and its incidence is increasing in both the United States and Europe [2-5]. Surgical resection and liver

\footnotetext{
* Correspondence: zhengyinliao@vip.sina.com

'Department of Abdominal Oncology, West China Hospital, West China Medical School, Sichuan University, No. 17 Renming Road, Chengdu 610000, People's Republic of China

Full list of author information is available at the end of the article
}

transplantation are effective for the treatment of $\mathrm{HCC}$ [6,7]. Nevertheless, the surgical options for HCC are often limited due to concurrent hepatic cirrhosis, poor liver function, or multiple lesions [6,8-10]. Unfortunately, liver transplantation plays a very small role in the treatment of HCC because of ethical problems and a shortage of liver donors $[11,12]$. Thus, various nonsurgical treatment methods have been developed, including transcatheter arterial chemoembolization, percutaneous ethanol injection (PEI), radiofrequency ablation (RFA), and percutaneous acid injection.

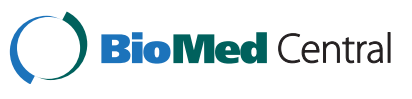

(c) 2015 Yang et al.; licensee BioMed Central. This is an Open Access article distributed under the terms of the Creative Commons Attribution License (http://creativecommons.org/licenses/by/4.0), which permits unrestricted use, distribution, and reproduction in any medium, provided the original work is properly credited. The Creative Commons Public Domain Dedication waiver (http://creativecommons.org/publicdomain/zero/1.0/) applies to the data made available in this article, unless otherwise stated. 
PEI was the first percutaneous technique introduced to clinical practice $[8,13]$. It is a simple, inexpensive, safe, effective technique with a low complication rate and can achieve complete necrosis of small HCC lesions [14-17]. Therefore, in 2001, the European Association for the Study of the Liver recommended PEI as the standard percutaneous treatment for early-stage, nonsurgical HCC [6]. However, PEI has some limitations, including the need for multiple treatment sessions and a prolonged treatment time [6].

In 1999, RFA was first conducted for the treatment of HCC in Japan [18]. Its advantages over PEI include ease of performance, effectiveness similar to that of surgical resection, high safety, and low invasiveness [19-22]. The American Association for the Study of Liver Diseases published guidelines in 2005 (updated in 2010) indicating that RFA is the first-choice procedure for patients with $\mathrm{HCC}$, especially patients with tumors that are $\leq 3 \mathrm{~cm}$ in diameter and comprise one to three nodules. However, PEI still plays an important role in the local treatment of early-stage $\mathrm{HCC}[6,23]$. Despite the advantages of RFA, complete ablation remains difficult to achieve in some specific liver sites; RFA is also more expensive than PEI $[21,24]$.

To the best of our knowledge, four Asian randomized controlled trials (RCTs) have indicated that RFA is superior to PEI in terms of overall survival (OS), complete response (CR), and local recurrence (LR) [25-28]. However, these trials may have included selection bias, as trials performed in Europe have shown no significant differences between RFA and PEI with respect to OS [16,29-32]. The most effective treatment strategy for patients with unresectable HCC thus remains controversial. The present meta-analysis was performed to compare the effects of RFA and PEI for the treatment of HCC.

\section{Methods}

\section{Search strategy}

The following databases were searched for all published and unpublished RCTs with no language restrictions: Excerpta Medica dataBASE (EMBASE), PubMed, Cochrane Central Register of Controlled Trials, Cochrane Methodology Register, Cochrane Database of Systematic Reviews, Cochrane Library, American Society of Clinical Oncology database (ASCO), China National Knowledge Infrastructure database (CNKI), Chinese Biomedical Literature (CBM) Database, Wanfang database, and the Chongqing VIP database (CQVIP). Combinations of the following terms were used in the search: medical subject headings = liver neoplasms, catheter ablation, ethanol, and injections intraregional; free text terms = hepatocellular carcinoma, liver cancer, liver tumor, radiofrequency ablation, RFA, ethanol injection, alcohol injection, and PEI. We also performed a supplementary literature search through Google
Scholar and some leading journals. The publication cutoff date was 14 March 2014. Each search strategy was determined after numerous pre-searches. The reference lists of all included studies were examined for relevant publications.

\section{Eligibility criteria}

All procedures were performed in compliance with the Declaration of Helsinki. This study was also approved by the Committee on the Ethics West China Hospital. The inclusion criteria were as follows: (i) studies including patients with unresectable lesions, Child-Pugh class A or $B$ liver function, and inclusion of both an RFA and PEI group (in studies comparing two or more arms); (ii) RFA as the intervention and PEI as the comparator; (iii) inclusion of data related to OS (percentage of patients who survived for a defined period of time after treatment), and at least one of the following secondary outcomes: LR (percentage of patients with newly detected liver tumors in the posttreatment follow-up period), CR (lower incidence of liver tumors posttreatment), and treatmentrelated adverse events or complications; and (iv) RCT was the study design.

The exclusion criteria were as follows: (i) phase 2 RCTs, (ii) lesions $>5 \mathrm{~cm}$ in diameter (ablation techniques alone are less effective in larger tumors [33]), and (iii) history of surgical treatment for $\mathrm{HCC}$.

\section{Assessment of study quality}

We used the Cochrane Collaboration handbook to assess the risk of bias in all included studies [34]. The quality items assessed included sequence generation, allocation concealment, baseline imbalance, double-blinding, incomplete outcome data, early stopping, and selective outcome reporting. For individual studies, each criterion was assigned a label of 'yes', 'unclear,' or 'no' to estimate the risk of bias. Two reviewers (Y.B. and W.S.Y.) performed the quality assessment. Any discrepancies were resolved by an intercessor (Z.R.Y.).

\section{Data extraction}

The two reviewers (Y.B. and W.S.Y.) independently extracted the following parameters from all included studies: basic information of the studies (authors, publication year, duration of study, region in which the study was performed, and randomization method), patient characteristics (age, sex, number and size of tumors, number of patients with hepatitis $B$ and $C$ virus infection, and liver function), information on the intervention and comparator evaluated in the study, and clinical outcomes (OS, LR, CR, and complications). Most original data were extracted directly from the trials, but some data regarding OS and LR were extracted from the published study curves using the software Engauge Digitizer (version 4.1) 
described by Parmar [35] and calculated using a Microsoft Excel spreadsheet provided by Tierney et al. [36].

\section{Outcome measures}

In this meta-analysis, the primary outcome was OS. The secondary outcomes were LR, CR, and the main treatment-related complications that occurred during the follow-up period.

\section{Statistical analysis}

The hazard ratio (HR) and 95\% confidence interval (CI) of the OS were calculated for each trial. Similarly, the risk ratio (RR) and 95\% CI of the LR and CR were determined. Subgroup analyses were performed to explore important clinical differences between European and Asian trials. Both random and fixed effects models were utilized $[37,38] . I^{2}$ and $\chi^{2}$ statistics of the HR were used to evaluate endpoint heterogeneity; studies with a $P<0.1$ and $I^{2}>50 \%$ were considered invalid, and the random effects model was used. Otherwise, the data were pooled using the fixed effects model. The significance of the pooled RR was determined by the $Z$-test, and $P<0.05$ was considered statistically significant. All data obtained in this metaanalysis were pooled and analyzed using the software program Review Manager (version 5.0). Microsoft Excel 2010 was used to calculate the data. The guidelines detailed in this review are described in the Cochrane handbook [34].

\section{Results}

\section{Study selection}

In total, 2,417 citations were identified in the search of the electronic databases (Figure 1); 687 duplicates were excluded, and 1,730 papers remained. We excluded 1,716

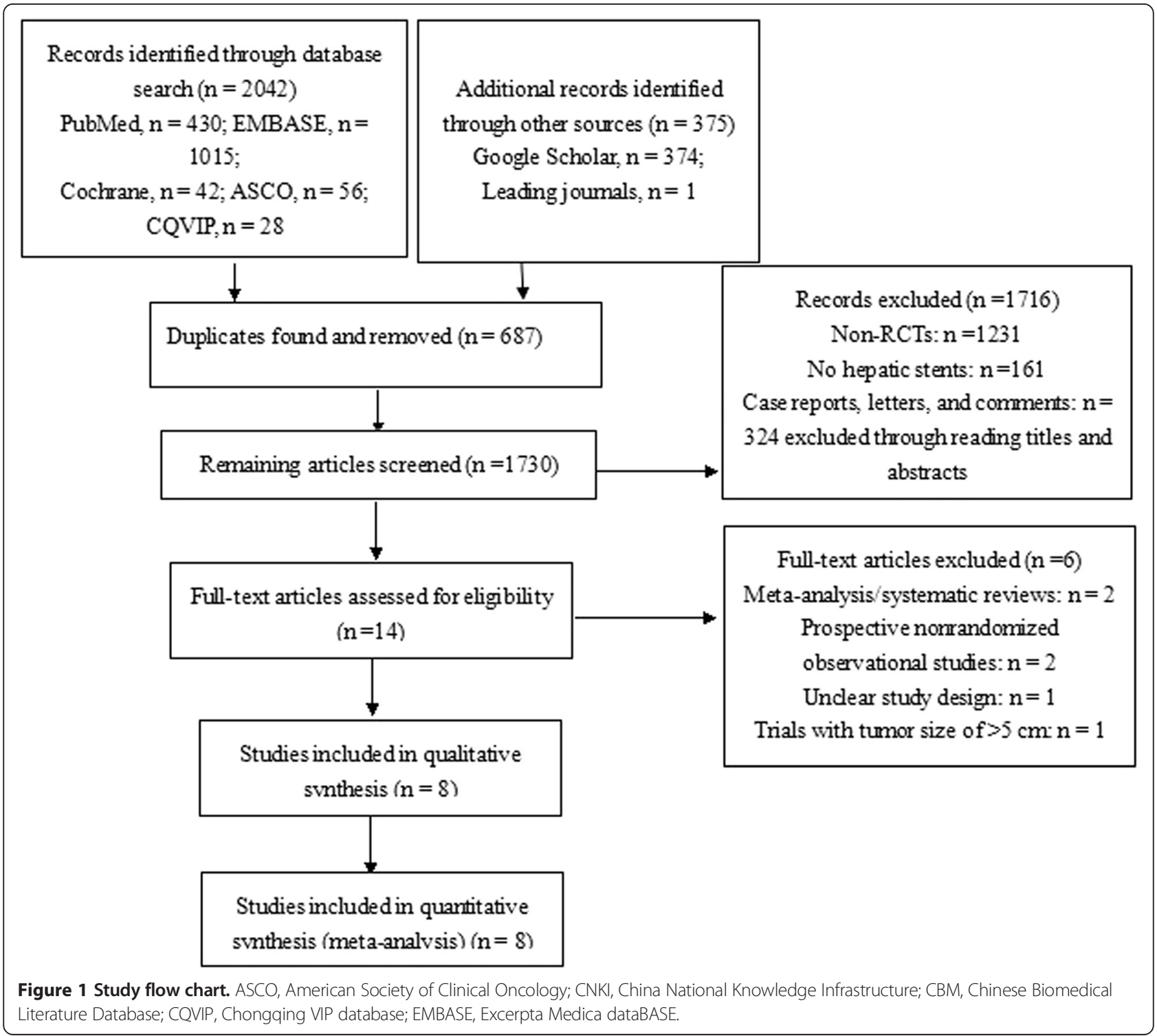


citations based on reading the title and abstract in our initial screening, and 14 full-text articles were read for further assessment. Two papers reported prospective studies without additional details. One prospective nonrandomized study was excluded after obtaining information via email from the author. However, we failed to contact the corresponding author of another prospective nonrandomized study and thus excluded this paper because of its unclear study design. The remaining papers were evaluated, and several more were excluded for the reasons listed in Figure 1. Finally, eight RCTs met all eligibility criteria and were included in this meta-analysis $[25-28,30,31,39,40]$. Three RCTs were conducted in Italy and were thus grouped as European studies [30,31,40], four originated from Asia (Taiwan, $n=2$ [25,26]; Japan, $n=1$ [27]; and China, $n=1$ [28]), and one study from Egypt was considered as an African study [39]. Although the two studies from Taiwan were performed in the same institution within 2 years, the corresponding author indicated that the randomized patients in these two studies did not overlap.

\section{Characteristics of included studies}

In total, 1,130 patients were included among all selected studies; 561 underwent RFA, and 569 underwent PEI. The RFA and PEI groups contained 319 and 320 patients with Child-Pugh class A liver function, respectively. The average number of treatment sessions per tumor ranged from 1.1 to 8.0. The male to female ratio was 1.97:1.00. The mean tumor size ranged from $2.25 \pm 0.45$ to $2.8 \pm 0.8 \mathrm{~cm}$. A total of 758 patients had a single lesion (RF, $n=381$; PEI, $n=377)$. The patients' baseline characteristics are presented in Table 1, and the details of the study endpoints are summarized in Table 2. Details on the quality of each included study are presented in Table 3. A total of 466 complications or adverse events occurred among all patients in all studies (RFA, $n=247$; PEI, $n=219$ ) (Table 4).

\section{Overall survival}

Sensitivity analysis did not change the significance of the results in the Asian studies. A fixed effects model was used because of a lack of significant heterogeneity as follows: Asia, $I^{2}=0 \%, P=0.98$; Europe, $I^{2}=0 \%, P=0.90$; and total, $I^{2}=0 \%, P=0.67$ (Figure 2). Total effect of comparison of RFA with PEI indicated that RFA was associated with better OS rates than PEI (HR, 0.67; 95\% CI 0.51 to $0.87 ; P<0.01$ ). In the Asian studies, RFA exhibited better performance than PEI in terms of OS (HR, 0.54; 95\% CI: 0.37 to $0.80 ; P<0.01$ ). However, no statistically significant difference was observed between the two treatments in the European studies (HR, 0.82; $95 \%$ CI 0.56 to $1.20 ; P=0.30$ ).

\section{Local recurrence rate}

Only five RCTs evaluated the LR because three did not report relevant data $[25-27,31,40]$. Only one study conducted in Europe reported the LR associated with a longterm follow-up; thus, a subgroup analysis with HR could not be performed. The RR was deemed to be an optimal indicator to obtain additional information from these original studies through comparison of RFA with PEI.

As shown in Figures 3 and 4, the pooled estimate of the treatment indicated that RFA was associated with a lower LR rate than was PEI at 1 year (RR, 0.44; 95\% CI 0.22 to $0.85 ; P=0.02)$ and 3 years (RR, $0.41 ; 95 \% \mathrm{CI} 0.30$ to $0.57 ; P<0.01)$. The same condition was found in the Asian studies at 1 year (RR, 0.44; $95 \%$ CI 0.20 to $0.95 ; P=0.04$ ) and 3 years (RR, $0.35 ; 95 \%$ CI 0.22 to $0.55 ; P<0.01)$. In the European studies, however, no significant differences were observed between the two treatment groups at 1 year (RR, $0.35 ; 95 \%$ CI 0.05 to $2.59 ; P=0.30)$ or 3 years (RR, $0.50 ; 95 \%$ CI 0.32 to $0.78 ; P<0.01)$. The European data showed heterogeneity at 1 year $\left(I^{2}=68 \%, P=0.08\right)$ and 3 years $\left(I^{2}=69 \%\right.$, $P=0.07)$. Thus, the random effects models were derived.

\section{Complete response}

All eight studies reported the CR rate after RFA or PEI, and six of them were suitable for pooling of the CR data (both RFA and PEI exhibited a 100\% CR rate in the two remaining studies $[27,31])$.

The total pooled data showed that RFA was associated with a better CR rate than PEI (RR, 1.15; 95\% CI 1.05 to 1.27; $P<0.01$ ) (Figure 5). A similar finding was observed in the Asian studies (RR, 1.10; 95\% CI 1.03 to $1.18 ; P<0.01$ ). However, no significant differences were found between the two treatment groups in the European studies (RR, 1.27 ; $95 \%$ CI 0.95 to $1.69 ; P=0.11$ ) or in the African study (RR, $1.09 ; 95 \%$ CI 0.84 to $1.40 ; P=0.52$ ).

\section{Complications}

The main adverse events in the two treatment groups are presented in Table 4. RFA was associated with more complications than was PEI ( $n=247$ and 219, respectively). The main differences between the two treatment groups involved the incidence of skin burns, hydrothorax, liver abscesses, hemothorax, and portal venous thrombosis.

\section{Sensitivity analysis and publication bias}

We performed a one-way sensitivity analysis to evaluate the stability of the meta-analysis with respect to the Asian studies. The sensitivity analysis did not change the significance of the results in the Asian studies. A sensitivity analysis was not performed for the European trials because only two studies were available [30,31]. A funnel plot indicated that no significant publication bias was observed in any of the studies (Figure 6). 


\section{Table 1 Study and patient characteristics of each randomized controlled trial}

\begin{tabular}{|c|c|c|c|c|c|c|c|c|c|c|c|c|c|c|c|c|}
\hline $\begin{array}{l}\begin{array}{l}\text { First } \\
\text { author, } \\
\text { year }\end{array} \\
\end{array}$ & Duration & Region & Randomization & $\begin{array}{l}\mathrm{Tx} \\
(n)\end{array}$ & $\begin{array}{l}\text { Age, } \\
\text { years }\end{array}$ & $\begin{array}{l}\text { Sex, } n \\
\text { (M/F) }\end{array}$ & $\begin{array}{l}\text { Child-Pugh, } \\
n(\mathrm{~A} / \mathrm{B})\end{array}$ & $\begin{array}{l}\text { Infection, } n \\
\text { (HBV/HCV/ } \\
\text { others) }\end{array}$ & $\begin{array}{l}\text { Tumors, } \\
n(1 />2)\end{array}$ & $\begin{array}{l}\begin{array}{l}\text { Ratio of } \\
\text { tumor, } n \\
(\leq 3 />3 \mathrm{~cm})\end{array} \\
\end{array}$ & $\begin{array}{l}\text { Tumor } \\
\text { size, cm }\end{array}$ & $\begin{array}{l}\text { Albumin, } \\
\text { g/dL }\end{array}$ & $\begin{array}{l}\text { Volume per } \\
\text { session, } \mathrm{mL}\end{array}$ & $\begin{array}{l}\text { Number of } \\
\text { sessions }\end{array}$ & $\begin{array}{l}\text { Follow-up, } \\
\text { months }\end{array}$ & $\begin{array}{l}\text { Jadad } \\
\text { score }\end{array}$ \\
\hline \multirow[t]{2}{*}{$\begin{array}{l}\text { Lencioni, } \\
2003\end{array}$} & $\begin{array}{l}\text { April } 2000 \text { to } \\
\text { April } 2002\end{array}$ & Italy & Computer & $\begin{array}{l}\text { RFA } \\
\text { (52) }\end{array}$ & $\begin{array}{l}6 \pm \\
6.0\end{array}$ & $36 / 16$ & $45 / 7$ & $6 / 22 / 24$ & $40 / 12$ & $46 / 6$ & $2.8 \pm 0.6$ & $4.1 \pm 0.7$ & NA & $1.1 \pm 0.5$ & $22.9 \pm 9.4$ & 4 \\
\hline & & & & $\begin{array}{l}\text { PEl } \\
(50)\end{array}$ & $\begin{array}{l}6 \pm \\
7.4\end{array}$ & $30 / 20$ & $35 / 15$ & $9 / 20 / 21$ & $31 / 19$ & $42 / 8$ & $2.8 \pm 0.8$ & $3.7 \pm 0.6$ & NA & $5.4 \pm 1.6$ & $22.4 \pm 8.6$ & \\
\hline \multirow[t]{2}{*}{ Lin, 2004} & $\begin{array}{l}\text { April } 2000 \text { to } \\
\text { April } 2002\end{array}$ & Taiwan & Computer & $\begin{array}{l}\text { RFA } \\
(52)\end{array}$ & $\begin{array}{l}62 \pm \\
11\end{array}$ & $35 / 17$ & $41 / 11$ & $35 / 16 / 1$ & $38 / 14$ & $37 / 15$ & $2.9 \pm 0.8$ & $3.7 \pm 0.8$ & NA & $1.6 \pm 0.4$ & $24.5 \pm 11.3$ & 4 \\
\hline & & & & $\begin{array}{l}\text { PEl } \\
(52)\end{array}$ & $\begin{array}{l}59 \pm \\
10\end{array}$ & $34 / 18$ & $39 / 12$ & $37 / 14 / 1$ & $40 / 12$ & $38 / 14$ & $2.8 \pm 0.8$ & $3.8 \pm 1.0$ & $\begin{array}{l}4.5(2.0- \\
10.0)\end{array}$ & $6.5 \pm 1.6$ & $23.8 \pm 10.4$ & \\
\hline \multirow[t]{2}{*}{ Lin, 2005} & $\begin{array}{l}\text { April } 2000 \text { to } \\
\text { April } 2003\end{array}$ & Taiwan & Computer & $\begin{array}{l}\text { RFA } \\
(62)\end{array}$ & $\begin{array}{l}61 \pm \\
10\end{array}$ & $40 / 22$ & $46 / 16$ & $41 / 20 / 1$ & $49 / 13$ & $62 / 0$ & $2.5 \pm 1.0$ & $4.0 \pm 0.6$ & & $1.3 \pm 0.3$ & $28 \pm 12$ & 4 \\
\hline & & & & $\begin{array}{l}\text { PEl } \\
(62)\end{array}$ & $\begin{array}{l}60 \pm \\
8\end{array}$ & $39 / 23$ & $47 / 15$ & $42 / 19 / 1$ & $49 / 13$ & $62 / 0$ & $2.3 \pm 0.8$ & $3.9 \pm 0.4$ & $\begin{array}{l}4.8(2.0- \\
10.4)\end{array}$ & $4.9 \pm 1.3$ & $26 \pm 13$ & \\
\hline \multirow[t]{2}{*}{$\begin{array}{l}\text { Shiina, } \\
2005\end{array}$} & $\begin{array}{l}\text { April } 1999 \text { to } \\
\text { January } 2001\end{array}$ & Japan & Computer & $\begin{array}{l}\text { RFA } \\
(118)\end{array}$ & $\begin{array}{l}44 / 71 \\
(\leq 65 /> \\
65)\end{array}$ & $79 / 39$ & $85 / 33$ & 18/90/10 & $72 / 46$ & $118 / 0$ & NA & $\begin{array}{l}60 / 58 \\
(\leq 3.5 /> \\
3.5)\end{array}$ & $2-8$ & $2.1 \pm 1.3$ & 37 & 4 \\
\hline & & & & $\begin{array}{l}\text { PEl } \\
(114)\end{array}$ & $\begin{array}{l}41 / 73 \\
(\geq 65 /> \\
65)\end{array}$ & $87 / 27$ & $85 / 29$ & $11 / 98 / 5$ & $60 / 54$ & $114 / 0$ & NA & $\begin{array}{l}49 / 65 \\
(\leq 3.5 /> \\
3.5)\end{array}$ & NA & $6.4 \pm 2.6$ & 35 & \\
\hline \multirow[t]{2}{*}{$\begin{array}{l}\text { Brunello, } \\
2008\end{array}$} & $\begin{array}{l}\text { January } 2001 \\
\text { to September } \\
2004\end{array}$ & Italy & Computer & $\begin{array}{l}\text { RFA } \\
(70)\end{array}$ & $\begin{array}{l}69.0 \pm \\
7.7\end{array}$ & $43 / 27$ & $39 / 31$ & $6 / 44 / 20$ & $54 / 16$ & $70 / 0$ & $\begin{array}{l}2.42 \pm \\
0.49\end{array}$ & $\begin{array}{l}3.45 \pm \\
0.69\end{array}$ & $2-20$ & NA & 26.1 & 4 \\
\hline & & & & $\begin{array}{l}\text { PEl } \\
(69)\end{array}$ & $\begin{array}{l}70.3 \pm \\
8.1\end{array}$ & $49 / 20$ & $39 / 30$ & $0 / 47 / 22$ & $54 / 15$ & $69 / 0$ & $\begin{array}{l}2.25 \pm \\
0.54\end{array}$ & $\begin{array}{l}3.42 \pm \\
0.55\end{array}$ & NA & NA & 25.3 & \\
\hline \multirow[t]{2}{*}{$\begin{array}{l}\text { Giorgio, } \\
2011\end{array}$} & $\begin{array}{l}\text { January } 2005 \\
\text { to January } \\
2010\end{array}$ & Italy & RNG & $\begin{array}{l}\text { RFA } \\
(128)\end{array}$ & $70 \pm 2$ & $\begin{array}{l}105 / \\
37\end{array}$ & $70 / 72$ & $61 / 81 / 0$ & 128 & $128 / 0$ & $\begin{array}{l}2.34 \pm \\
0.45\end{array}$ & $\begin{array}{l}3.37 \pm \\
0.87\end{array}$ & $\begin{array}{l}8.7(4.0- \\
20.0)\end{array}$ & 5 & 22 & 4 \\
\hline & & & & $\begin{array}{l}\text { PEI } \\
(143)\end{array}$ & $72 \pm 6$ & $\begin{array}{l}102 / \\
41\end{array}$ & $75 / 68$ & $56 / 87 / 0$ & 143 & $143 / 0$ & $\begin{array}{l}2.27 \pm \\
0.48\end{array}$ & $\begin{array}{l}3.41 \pm \\
0.92\end{array}$ & NA & 8 & 22 & \\
\hline \multirow[t]{2}{*}{$\begin{array}{l}\text { Wang, } \\
2011\end{array}$} & $\begin{array}{l}\text { January } 2001 \\
\text { to March } \\
2009\end{array}$ & China & NA & $\begin{array}{l}\text { RFA } \\
(49)\end{array}$ & 43 & $35 / 14$ & NA & NA & NA & NA & $2.4 \pm 1.2$ & NA & NA & NA & $11.2 \pm 1.3$ & 2 \\
\hline & & & & $\begin{array}{l}\text { PEl } \\
(49)\end{array}$ & 45 & $36 / 13$ & NA & NA & NA & NA & $2.3 \pm 1.4$ & NA & & NA & $11.2 \pm 1.3$ & \\
\hline \multirow[t]{2}{*}{$\begin{array}{l}\text { Azab, } \\
2011\end{array}$} & 2005 to 2008 & Egypt & NA & $\begin{array}{l}\text { RFA } \\
(30)\end{array}$ & NA & NA & NA & NA & NA & $16 / 17$ & NA & NA & $3-14$ & 1.45 & NA & 3 \\
\hline & & & & $\begin{array}{l}\text { PEl } \\
(30)\end{array}$ & NA & NA & NA & NA & NA & $16 / 16$ & NA & NA & & 7.68 & NA & \\
\hline
\end{tabular}

$\mathrm{HBV}$, hepatitis B virus; HCV, hepatitis C virus; NA, not available; PEl, percutaneous ethanol injection; RFA, radiofrequency ablation; RNG, random number generator; Tx, treatment.

Data are presented as mean \pm standard deviation or mean (range). 
Table 2 Efficacy of radiofrequency ablation versus percutaneous ethanol injection for treatment of hepatocellular carcinoma

\begin{tabular}{|c|c|c|c|c|c|c|c|c|c|c|c|c|}
\hline \multirow{2}{*}{$\begin{array}{l}\text { First author, } \\
\text { year }\end{array}$} & \multirow{2}{*}{$\begin{array}{l}\text { Treatment } \\
(n)\end{array}$} & \multirow{2}{*}{$\begin{array}{l}\text { Complete } \\
\text { response (\%) }\end{array}$} & \multicolumn{5}{|c|}{ Overall survival (\%) } & \multicolumn{5}{|c|}{ Local recurrence (\%) } \\
\hline & & & 1-year & 2-year & 3-year & 4-year & 5-year & 1-year & 2-year & 3-year & 4-year & 5-year \\
\hline \multirow[t]{2}{*}{ Lencioni, 2003} & RFA (52) & 91.0 & 100.0 & 98.0 & NA & NA & NA & 2 & 4 & $21+$ & NA & NA \\
\hline & PEI (50) & 82.0 & 96.0 & 88.0 & NA & NA & NA & 17.0 & 38.0 & $59.0+$ & NA & NA \\
\hline \multirow[t]{2}{*}{ Lin, 2004} & RFA (52) & 96.0 & 90.0 & 82.0 & 74.0 & NA & NA & 12.0 & 18.0 & 18.0 & NA & NA \\
\hline & PEI (52) & 88.0 & 85.0 & 61.0 & 50.0 & NA & NA & 23.0 & 45.0 & 45.0 & NA & NA \\
\hline \multirow[t]{2}{*}{ Lin, 2005} & RFA (62) & 96.1 & 93.0 & 81.0 & 74.0 & NA & NA & 10.0 & 14.0 & 14.0 & NA & NA \\
\hline & PEI (62) & 88.1 & 88.0 & 66.0 & 51.0 & NA & NA & 16.0 & 34.0 & 34.0 & NA & NA \\
\hline \multirow[t]{2}{*}{ Shiina, 2005} & RFA (118) & 100.0 & $96.0+$ & $91.0+$ & $81.0+$ & 74.0 & NA & $1.0+$ & $1.7+$ & $1.7+$ & $1.7+$ & NA \\
\hline & PEI (114) & 100.0 & $93.0+$ & $81.0+$ & $66.0+$ & 57.0 & NA & $9.0+$ & $11.0+$ & $11.0+$ & $11.0+$ & NA \\
\hline \multirow[t]{2}{*}{ Brunello, 2008} & RFA (70) & 95.7 & $94.0+$ & $77.0+$ & $59.0+$ & $44.0+$ & NA & NA & NA & NA & NA & NA \\
\hline & PEI (69) & 65.6 & $87.0+$ & $74.0+$ & $56.0+$ & $42.0+$ & NA & NA & NA & NA & NA & NA \\
\hline \multirow[t]{2}{*}{ Giorgio, 2011} & RFA (128) & 100.0 & 95.0 & 90.0 & 83.0 & 73.0 & 70.0 & 4.1 & 5.7 & 7.8 & 8.9 & 11.7 \\
\hline & PEI (143) & 100.0 & 95.0 & 83.0 & 78.0 & 70.0 & 68.0 & 5.2 & 6.7 & 9.4 & 11.5 & 12.8 \\
\hline \multirow[t]{2}{*}{ Wang, 2011} & RFA (49) & 93.8 & 95.9 & 91.8 & NA & NA & NA & NA & NA & NA & NA & NA \\
\hline & PEI (49) & 77.5 & 85.7 & 77.5 & NA & NA & NA & NA & NA & NA & NA & NA \\
\hline \multirow[t]{2}{*}{ Azab, 2011} & RFA (30) & 85.0 & 90.0 & NA & NA & NA & NA & NA & NA & NA & NA & NA \\
\hline & PEI (30) & 75.0 & 83.3 & NA & NA & NA & NA & NA & NA & NA & NA & NA \\
\hline
\end{tabular}

NA, not available; PEl, percutaneous ethanol injection; RFA, radiofrequency ablation.

+ , data extracted from survival curves.

\section{Discussion}

The results from the Asian studies included in this meta-analysis indicate that RFA is superior to PEI in terms of OS, CR, and LR for patients with early-stage nonsurgical HCC, which are consistent with previous studies [24,41-47]. However, in the Asian studies included in the present analysis, carcinomas near vessels were treated only with PEI, and not by RFA, which can lead to a bad prognosis. The resulting selection bias likely influenced the apparent superiority of RFA, as evidenced by the lack of difference between the techniques in the European studies. Although pooled data reported by Weis et al. [45] indicated that RFA is superior to PEI, their sub-analysis also showed no evidence for prolonged $O S$ in European patients treated with RFA compared with PEI. The findings of this meta-analysis indicate that there is insufficient evidence to conclude that RFA is superior to PEI in patients with HCC tumors $\leq 5 \mathrm{~cm}$, consistent with the results of a systematic review of the same trials [48]. Moreover, the effect of both treatments is similar for patients with small HCC tumors $(<2 \mathrm{~cm})$, as demonstrated by studies from Cho et al. [14] and Germani et al. [44].

There are several potential factors affecting the discrepancy between our overall findings on overall survival and previous analyses. First, race may be a latent factor that requires consideration and should not be ignored. We failed to determine the impact of race because of the shortage of required evidence. Second, the proportion of patients with Child-Pugh class B cirrhosis was higher in

Table 3 Risk of bias in the trials included in the present meta-analysis

\begin{tabular}{|c|c|c|c|c|c|c|c|c|}
\hline Bias & Lencioni, 2003 & Lin, 2004 & Lin, 2005 & Shiina, 2005 & Brunello, 2008 & Giorgio, 2011 & Wang, 2011 & Azab, 2011 \\
\hline Sequence generation & + & + & + & + & + & + & $?$ & $?$ \\
\hline Allocation concealment & $?$ & $?$ & ? & $?$ & + & + & $?$ & $?$ \\
\hline Double-blinding & - & - & - & - & - & - & - & - \\
\hline Incomplete outcome data & - & + & - & + & - & - & - & - \\
\hline Selective outcome reporting & - & - & - & - & + & - & - & - \\
\hline Other sources of bias & - & + & + & - & - & - & - & + \\
\hline Early stopping & $?$ & - & - & - & + & - & - & - \\
\hline Baseline imbalance & - & - & - & - & - & - & - & - \\
\hline
\end{tabular}

+, yes; -, no; ?, unclear. 
Table 4 Major complications associated with radiofrequency ablation and percutaneous ethanol injection

\begin{tabular}{lll}
\hline Complication & RFA $(\boldsymbol{n}=\mathbf{2 4 7})$ & PEI $(\boldsymbol{n}=\mathbf{2 1 9})$ \\
\hline Fever & 58 & 52 \\
Skin burns & 6 & 0 \\
Ascites & 59 & 48 \\
Jaundice & 7 & 6 \\
Liver abscess & 0 & 2 \\
Gastric bleeding & 1 & 1 \\
Pain & 98 & 100 \\
Hydrothorax & 8 & 0 \\
Hemothorax & 4 & 1 \\
Subcapsular hematoma & 1 & 0 \\
Portal venous thrombosis & 5 & 9 \\
\hline
\end{tabular}

the two European studies than in the Asian studies. This suggests that patients with Child-Pugh A liver function treated with RFA have better outcomes, as indicated by findings reported by Brunello et al. [30] and Giorgio et al. [31]. Third, the limited number of smaller-scope studies evaluating RFA gives rise to selection bias. Fourth, the location of tumors can influence outcomes, as Bruix and Sherman [23] stated that RFA can increase the risk of severe complications in tumors located at high-risk sites. Giorgio et al. [31] reported that tumors located in the seventh and second liver segments are more suitable for treatment by PEI than by RFA. Similarly, Ebara et al. [49] found that $25 \%$ of lesions could not be treated by RFA because of the unfavorable location of the tumor. The exclusion criteria in two Asian studies in this meta-analysis included tumors located within 5 to $10 \mathrm{~mm}$ of the liver hila or the common bile duct [25-27], which are associated with a risk of injury to the major bile duct following RFA as reported by Brunello et al. [30] and Giorgio et al. [31]. Fifth, there is a lack of long-term data on patient survival; the RCTs that evaluated the two percutaneous treatments were small and had a short follow-up period. We found that the OS in both groups became more similar as the follow-up period lengthened, consistent with findings reported by Shen et al. [43] and Bouza et al. [24]. This is a critical factor that was not considered in previous meta-analyses $[41,42,47]$. Sixth, only four of the included trials reported the pathologic stage of the tumors, which were unclear and may have induced a bias effect in our study.

Similar results were found for LR and CR in the comparison between RFA and PEI. Both the total pooled data and subgroup meta-analysis results of the Asian studies implied that RFA is superior to PEI, consistent with the results of five other meta-analyses [24,41-44]. However, these findings may also be unreliable for the reasons listed above. The results of the European and African studies indicated no differences in LR at 1 year, but a significant discrepancy was present at 3 years [31]. Very similar results were obtained by Giorgio et al. [16]. Such findings suggest that RFA provides local tumor control and more $\mathrm{CR}$ than does PEI when the follow-up time is prolonged, but additional studies are needed to more thoroughly evaluate this.

\begin{tabular}{|c|c|c|c|c|c|c|}
\hline Stucty or Subgroup & log[Hazard Ratio] & SE & Weight & $\begin{array}{l}\text { Hazard Ratio } \\
\text { IV. Fixed. } 95 \% \mathrm{Cl}\end{array}$ & $\begin{array}{l}\text { Hazard Ratio } \\
\text { IV. Fixed, } 95 \% \mathrm{Cl}\end{array}$ & \\
\hline \multicolumn{7}{|l|}{ 7.1.1 Europe } \\
\hline Brunello 2008 & -0.198 & 0.275 & $25.5 \%$ & $0.82[0.48,1.41]$ & \begin{tabular}{l|l}
-1 \\
\end{tabular} & \\
\hline Giorgio 2011 & -0.21 & 0.28 & $24.6 \%$ & $0.81[0.47,1.40]$ & & \\
\hline Subtotal $(95 \% \mathrm{Cl})$ & & & $50.1 \%$ & $0.82[0.56,1.20]$ & & \\
\hline \multicolumn{7}{|c|}{$\begin{array}{l}\text { Heterogeneity: } \text { Chi }^{2}=0.00, d f=1(P=0.98) ; l^{2}=0 \% \\
\text { Test for overall effect: } Z=1.04(P=0.30)\end{array}$} \\
\hline \multicolumn{7}{|l|}{ 7.1.2 Asian } \\
\hline Lin 2004 & -0.67 & 0.39 & $12.7 \%$ & $0.51[0.24,1.10]$ & & \\
\hline $\operatorname{Lin} 2005$ & -0.7 & 0.35 & $15.8 \%$ & $0.50[0.25,0.99]$ & & \\
\hline Shiina 2005 & -0.51 & 0.3 & $21.4 \%$ & $0.60[0.33,1.08]$ & & \\
\hline Subtotal $(95 \% \mathrm{Cl})$ & & & $49.9 \%$ & $0.54[0.37,0.80]$ & & \\
\hline \multicolumn{7}{|c|}{$\begin{array}{l}\text { Heterogeneity: } C^{2} i^{2}=0.20, d f=2(P=0.90) ; I^{2}=0 \% \\
\text { Test for overall effect: } Z=3.10(P=0.002)\end{array}$} \\
\hline Total $(95 \% \mathrm{Cl})$ & & & $100.0 \%$ & $0.67[0.51,0.87]$ & & \\
\hline \multicolumn{7}{|c|}{$\begin{array}{l}\text { Heterogeneity: } C h i^{2}=2.35, d f=4(P=0.67) ; I^{2}=0 \% \\
\text { Test for overall effect: } Z=2.93(P=0.003) \\
\text { Test for subaroun differences: } C h i^{2}=2.14 . d f=1(P=0.14) . I^{2}=53.4 \%\end{array}$} \\
\hline \multicolumn{7}{|c|}{$\begin{array}{l}\text { Figure } 2 \text { Comparison of overall survival between radiofrequency ablation and percutaneous ethanol injection for hepatocellular } \\
\text { carcinoma (fixed effects model). Cl, confidence interval; HR, hazard ratio; PEI, percutaneous ethanol injection; RFA, radiofrequency ablation; } \\
\text { SE, standard error. }\end{array}$} \\
\hline
\end{tabular}




\begin{tabular}{|c|c|c|c|c|c|c|c|c|}
\hline \multirow[b]{2}{*}{ Studv or Subgroup } & \multicolumn{2}{|c|}{ Experimental } & \multicolumn{2}{|c|}{ Control } & & Risk Ratio & \multirow{2}{*}{\multicolumn{2}{|c|}{$\begin{array}{l}\text { Risk Ratio } \\
\text { M-H, Random, } 95 \% \mathrm{Cl}\end{array}$}} \\
\hline & Events & Total & Events & Total & Weight $\mathbb{N}$ & M-H, Random, $95 \% \mathrm{Cl}$ & & \\
\hline \multicolumn{9}{|c|}{ Leso } \\
\hline Giorgio 2011 & 5 & 128 & 7 & 143 & $23.1 \%$ & $0.80[0.26,2.45]$ & & \\
\hline Lencioni 2003 & 1 & 52 & 9 & 50 & $9.4 \%$ & $0.11[0.01,0.81]$ & & \\
\hline Subtotal $(95 \% \mathrm{Cl})$ & & 180 & & 193 & $32.5 \%$ & $0.35[0.05,2.59]$ & & \\
\hline Total events & 6 & & 16 & & & & & \\
\hline \multicolumn{9}{|c|}{$\begin{array}{l}\text { Heterogeneity: } \operatorname{Tau}^{2}=1.47 ; \mathrm{Chi}^{2}=3.10, \mathrm{df}=1(\mathrm{P}=0.08) ; \mathrm{I}^{2}=68 \% \\
\text { Test for overall effect: } Z=1.03(\mathrm{P}=0.30)\end{array}$} \\
\hline \multicolumn{9}{|l|}{ 4.1.2 Asian } \\
\hline $\operatorname{Lin} 2004$ & 6 & 52 & 12 & 52 & $29.9 \%$ & $0.50[0.20,1.23]$ & & \\
\hline Lin 2005 & 6 & 62 & 10 & 62 & $28.3 \%$ & $0.60[0.23,1.55]$ & $\rightarrow$ & + \\
\hline Shiina 2005 & 1 & 118 & 10 & 114 & $9.3 \%$ & $0.10[0.01,0.74]$ & & \\
\hline Subtotal $(95 \% \mathrm{Cl})$ & & 232 & & 228 & $67.5 \%$ & $0.44[0.20,0.95]$ & & \\
\hline Total events & 13 & & 32 & & & & & \\
\hline \multicolumn{9}{|c|}{$\begin{array}{l}\text { Heterogeneity: } \operatorname{Tau}^{2}=0.14 ; \mathrm{Chi}^{2}=2.78, \mathrm{df}=2(P=0.25) ; i^{2}=28 \% \\
\text { Test for overall effect: } Z=2.09(P=0.04)\end{array}$} \\
\hline Total $(95 \% \mathrm{Cl})$ & & 412 & & 421 & $100.0 \%$ & $0.44[0.22,0.85]$ & & \\
\hline Total events & 19 & & 48 & & & & & \\
\hline \multicolumn{9}{|c|}{$\begin{array}{l}\text { Heterogeneity: } \mathrm{Tau}^{2}=0.18 ; \mathrm{Chi}^{2}=5.87, \mathrm{df}=4(P=0.21) ; \mathrm{I}^{2}=32 \% \\
\text { Test for overall effect: } \mathrm{Z}=2.42(\mathrm{P}=0.02) \\
\text { Test for subaroun differences: } \mathrm{Chi}^{2}=0.04 . \mathrm{df}=1(\mathrm{P}=0.83) . \mathrm{I}^{2}=0 \%\end{array}$} \\
\hline $\begin{array}{l}\text { Figure } 3 \text { Comparison } \\
\text { hepatocellular carcin } \\
\text { RR, risk ratio. }\end{array}$ & $\begin{array}{l}\text { of one-ye } \\
\text { ma (rand }\end{array}$ & $\begin{array}{l}\text { ar local } \\
\text { om effec }\end{array}$ & $\begin{array}{l}\text { recurren } \\
\text { cts mod }\end{array}$ & $\begin{array}{l}\text { ice rat } \\
\text { el). Cl, }\end{array}$ & $\begin{array}{l}\text { tes betwee } \\
\text { confidence }\end{array}$ & $\begin{array}{l}\text { en radiofrequency ablati } \\
\text { interval; PEl, percutaneous }\end{array}$ & $\begin{array}{l}\text { percutaneous } \\
\text { injection; RFA, }\end{array}$ & $\begin{array}{l}\text { s ethanol injection for } \\
\text { radiofrequency ablation; }\end{array}$ \\
\hline
\end{tabular}

We did not pool the total number of complications among all patients in the RFA and PEI groups. However, the total number of adverse events found in this metaanalysis suggests that RFA may be associated with a higher rate of adverse events, as reported by other studies
[24,41-44]. This may be explained by the fact that the diameter of the RFA electrode needle is larger than that of the PEI needle, potentially leading to a higher risk of complications such as hemothorax. On the other hand, the temperature may quickly diffuse to a larger region

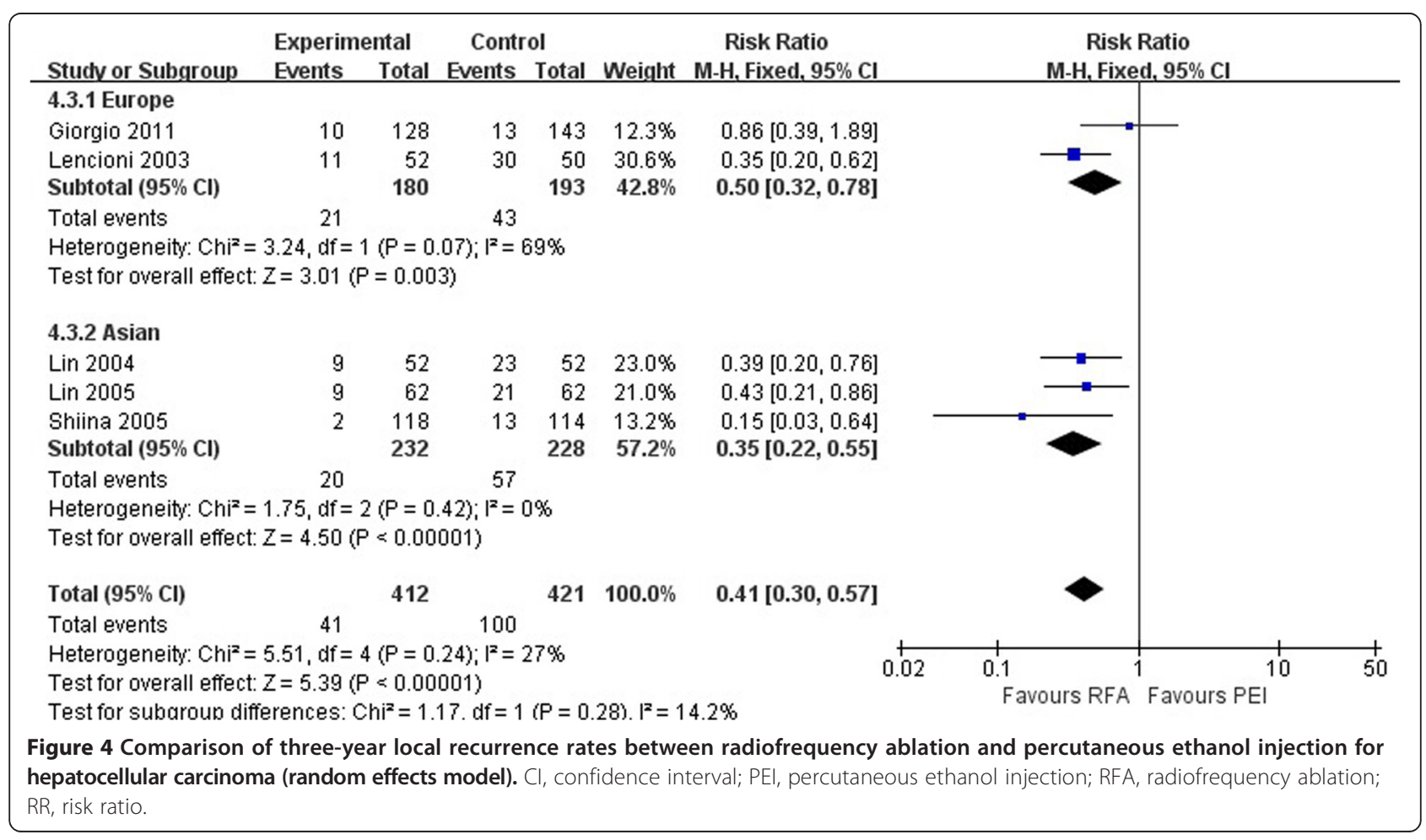




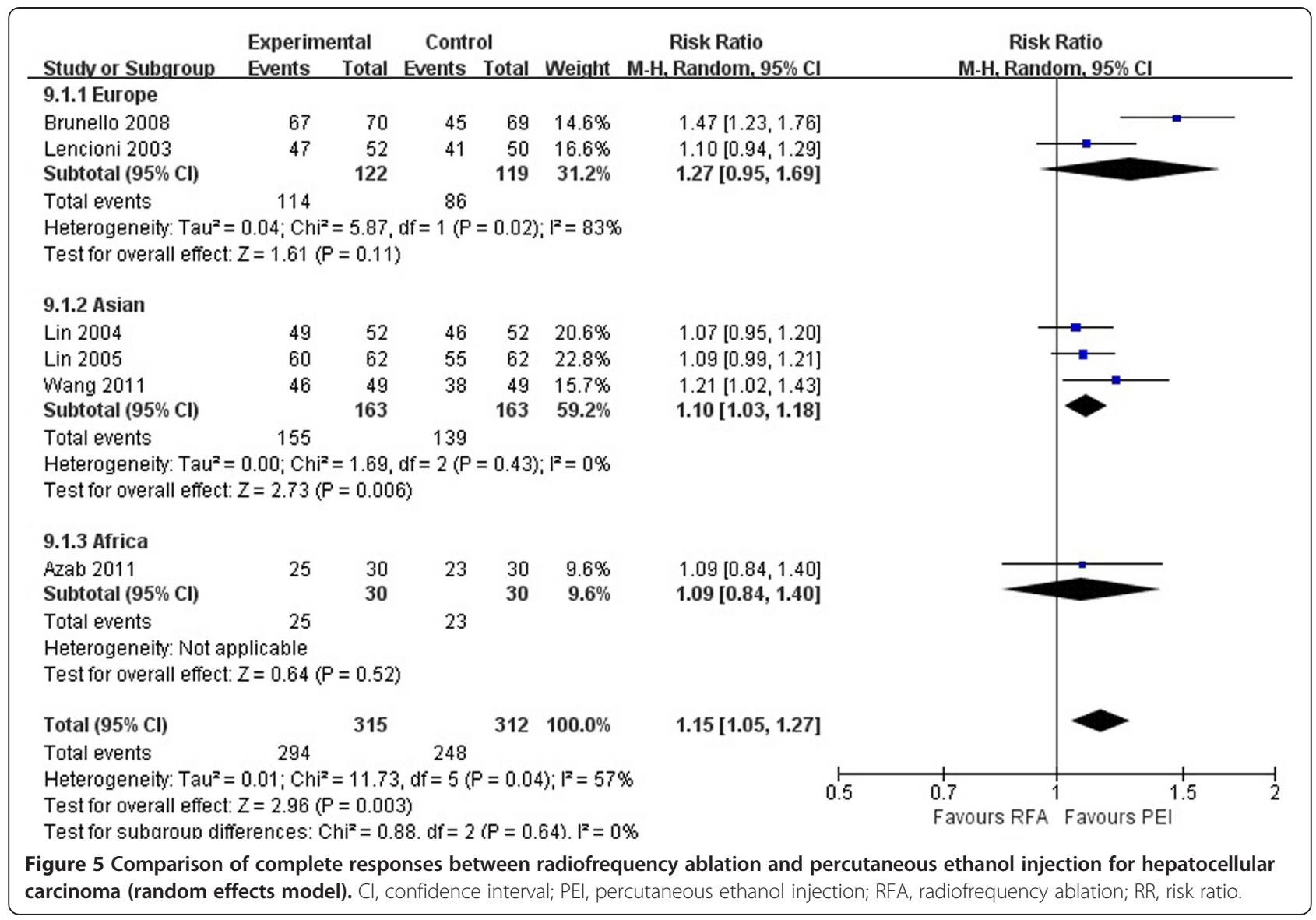

during the performance of RFA. Temperature diffusion is difficult to control and may readily lead to complications such as skin burns. Therefore, for small HCC, PEI is associated with fewer complications and a broader scope of treatment indications than RFA.

\section{Limitations of this study}

We acknowledge that the conclusions of this metaanalysis are limited by various factors. First, a small number of relevant studies were included. This may have led to false-negative or false-positive conclusions. In particular,

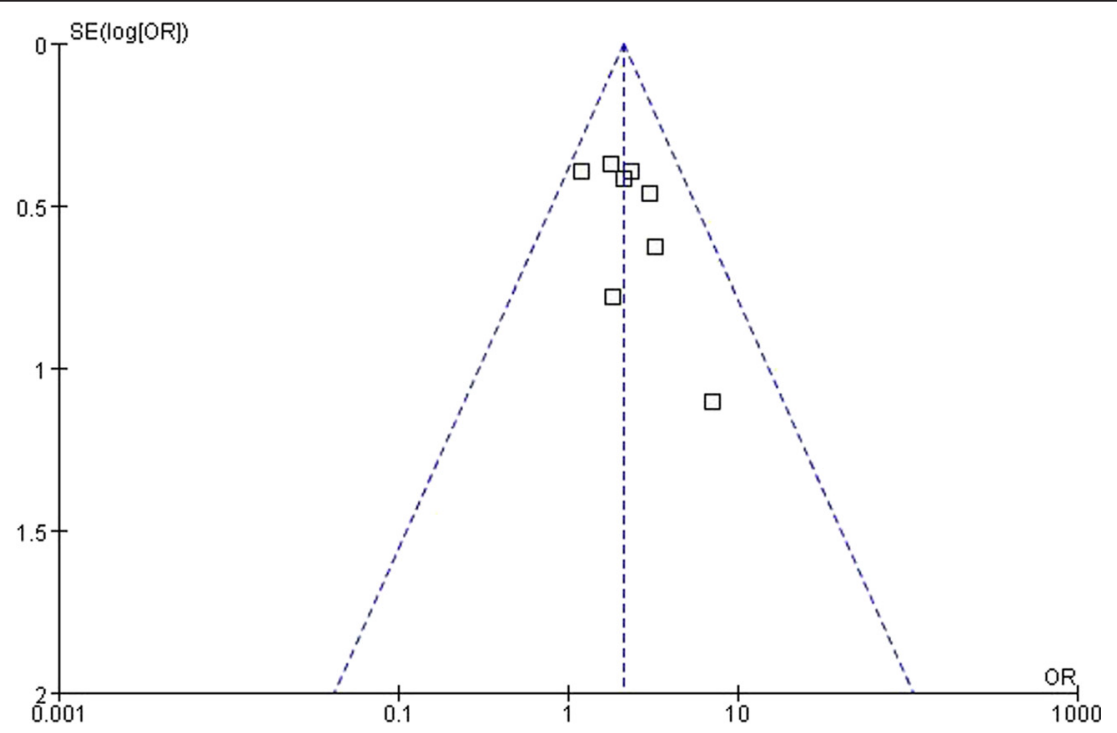

Figure 6 Funnel plot for assessment of publication bias in included studies. OR, odds ratio; SE, standard error. 
only two European trials compared the OS and LR. Although the sensitivity analysis did not change the significance of the results, the outcomes of the European trials are still weakened. Second, only five studies presented survival curves or HR-related data. Third, some trials did not involve a randomization procedure, which may have affected the accuracy of the outcomes $[22,36]$. Third, none of the trials blinded the treatment providers because of the nature of the interventional operation. Fortunately, the primary outcome was not affected by blinding because the studies reported the mortality rates [50]. Fourth, however, the secondary outcomes may have been affected by performance and detection bias, which may have resulted in imprecise findings of this meta-analysis. Fifth, the baseline characteristics of the included studies, such as tumor size, number of lesions, and different technical procedures, may have limited the accuracy of the pooled data. Sixth, some data were directly extracted from the OS and LR curves because of the lack of original data. Although we did our best to extract and calculate the necessary data using the software Engauge Digitizer [36], some error is inevitable. Nevertheless, the Cochrane Collaborative Group recommends that not all data need to be perfectly accurate when some patient data are lacking [34]. Seventh, none of the trials were powerful enough to identify differences in OS because of small sample sizes and short follow-up durations. Finally, heterogeneity was found in the studies included in this meta-analysis. This may be explained by the fact that more patients had hepatitis B infection, higher $\alpha$-fetoprotein levels, and the inclusion of HCC nodules of $>5 \mathrm{~cm}$ in the study by Lencioni et al. [40]. However, technologic disparity among the studies may the most important reason for the observed heterogeneity.

A number of credible techniques were used to reduce potential bias, including an extensive search of the literature, strict guidelines regarding duplicate data extraction, the use of clear criteria, and the use of a random effects model for effect estimation and contacting the corresponding authors by email. In spite of all the above-described limitations, this study provides the most thorough comparison of RFA and PEI.

\section{Conclusion}

The findings of the present meta-analysis indicate that there is no reliable evidence to support the idea that RFA is superior to PEI for patients, especially in Europe, with cirrhotic HCC. Additional large-scale RCTs with less selection bias are still needed.

\section{Competing interests}

The authors declare that they have no competing interests.

\section{Authors' contributions}

YB, WSY, WML, and LJ participated in the study design; YB and WSY participated in the collection, analysis, and extraction of data and drafted the manuscript; ZRY resolved all discrepancies as an intercessor; GWH and YX revised the manuscript; $L X L$ contributed to the statistical analyses; LZY conceived of the study, participated in its design and coordination, and helped draft the manuscript. All authors read and approved the final manuscript.

\section{Acknowledgements}

No support from any organization was received for the submitted work.

\section{Author details}

${ }^{1}$ Department of Abdominal Oncology, West China Hospital, West China Medical School, Sichuan University, No. 17 Renming Road, Chengdu 610000, People's Republic of China. ${ }^{2}$ Department of Radiology, Shanghai Children's Medical Center, Shanghai Jiao Tong University School of Medicine, Shanghai 200025, China. ${ }^{3}$ Chinese Evidence-Based Medicine Centre, West China Hospital, West China Medical School, Sichuan University, No. 17 Renming Road, Chengdu 610000, China.

Received: 19 November 2014 Accepted: 14 February 2015

Published online: 08 March 2015

\section{References}

1. Forner A, Bruix J. Hepatocellular carcinoma-authors' reply. Lancet. 2012;380:470-1.

2. El-Serag HB, Mason AC. Rising incidence of hepatocellular carcinoma in the United States. N Engl J Med. 1999;340:745-50.

3. Taylor-Robinson SD, Foster GR, Arora S, Hargreaves S, Thomas HC. Increase in primary liver cancer in the UK, 1979-94. Lancet. 1997;350:1142-3.

4. Okuda K. Primary liver cancers in Japan. Cancer. 1980;45:2663-9.

5. Llovet JM. Updated treatment approach to hepatocellular carcinoma. J Gastroenterol. 2005;40:225-35.

6. Bruix J, Sherman M. Practice Guidelines Committee AAftSoLD. Manag Hepatocell Carcinoma Hepatol. 2005;42:1208-12036.

7. Dusheiko G, Burroughs A, Hobbs K, Dick R. Treatment of small hepatocellular carcinomas. Lancet. 1992;340:285-8.

8. Ryder SD. Guidelines for the diagnosis and treatment of hepatocellular carcinoma (HCC) in adults. Gut. 2003;52:iii1-8.

9. Llovet JM, Burroughs A, Bruix J. Hepatocellular carcinoma. Lancet. 2003;362:1907-17.

10. Colombo M, Sangiovanni A. The European approach to hepatocellular carcinoma. Hepatogastroenterology. 2002;49:12-6.

11. Surman OS, Hertl M. Liver donation: donor safety comes first. Lancet. 2003;362:674-5.

12. Singer PA, Siegler M, Whitington PF, Lantos JD, Emond JC, Thistlethwaite JR, et al. Ethics of liver transplantation with living donors. N Engl J Med. 1989;321:620-2.

13. Sugiura N, Takara K, Ohto M, Okuda K, Hirooka N. Treatment of small hepatocellular carcinoma by percutaneous injection of ethanol into tumor with real-time ultrasound monitoring. Acta Hepatol Jpn. 1983;24:920.

14. Cho YK, Kim JK, Kim MY, Rhim H, Han JK. Systematic review of randomized trials for hepatocellular carcinoma treated with percutaneous ablation therapies. Hepatology. 2009;49:453-9.

15. Sala M, Llovet JM, Vilana R, Bianchi L, Solé M, Ayuso C, et al. Initial response to percutaneous ablation predicts survival in patients with hepatocellular carcinoma. Hepatology. 2004;40:1352-60.

16. Giorgio A. Percutaneous ethanol injection in the treatment of hepatocellular carcinoma in cirrhosis: a simple, effective and cheap procedure for percutaneous ablation. J Gastrointestin Liver Dis. 2010;19:461-7.

17. Shiina S, Tagawa K, Niwa Y, Unuma T, Komatsu Y, Yoshiura K, et al. Percutaneous ethanol injection therapy for hepatocellular carcinoma: results in 146 patients. AJR Am J Roentgenol. 1993;160:1023-8.

18. Kudo M. Radiofrequency ablation for hepatocellular carcinoma: updated review in 2010. Oncology. 2010;78 Suppl 1:113-24.

19. Ishikawa T. Strategy for improving survival and reducing recurrence of HCV-related hepatocellular carcinoma. World J Gastroenterol. 2013;19:6127-30.

20. Curley SA, Marra P, Beaty K, Ellis LM, Vauthey JN, Abdalla EK, et al. Early and late complications after radiofrequency ablation of malignant liver tumors in 608 patients. Ann Surg. 2004;239:450-8. 
21. Minami Y, Kudo M. Radiofrequency ablation of hepatocellular carcinoma: current status. World J Radiol. 2010;2:417-24.

22. Chiou YY, Chou YH. Radiofrequency ablation of hepatocellular carcinoma. J Med Ultrasound. 2008;16:272-84.

23. Bruix J, Sherman M. American Association for the Study of Liver D. Manag Hepatocell Carcinoma. 2011;53:1020-2.

24. Bouza C, Lopez-Cuadrado T, Alcazar R, Saz-Parkinson Z, Amate JM. Meta-analysis of percutaneous radiofrequency ablation versus ethanol injection in hepatocellular carcinoma. BMC Gastroenterol. 2009;9:31.

25. Lin SM, Lin CJ, Lin CC, Hsu CW, Chen YC. Radiofrequency ablation improves prognosis compared with ethanol injection for hepatocellular carcinoma $\leq 4 \mathrm{~cm}$. Gastroenterology. 2004;127:1714-23.

26. Lin SM, Lin CJ, Lin CC, Hsu CW, Chen YC. Randomised controlled trial comparing percutaneous radiofrequency thermal ablation, percutaneous ethanol injection, and percutaneous acetic acid injection to treat hepatocellular carcinoma of $3 \mathrm{~cm}$ or less. Gut. 2005:54:1151-6.

27. Shiina S, Teratani T, Obi S, Sato S, Tateishi R, Fujishima T, et al. A randomized controlled trial of radiofrequency ablation with ethanol injection for small hepatocellular carcinoma. Gastroenterology. 2005;129:122-30.

28. Xue-wen $W$, Sen $Y$, Zhao L, Xiao-fei H. Clinical effect of radiofrequency ablation therapy and percutaneous ethanol injection therapy on small hepatocellular carcinoma. Med J West China. 2011;23:1671-3.

29. Signoriello S, Annunziata A, Lama N, Signoriello G, Chiodini P, De Sio I, et al. Survival after locoregional treatments for hepatocellular carcinoma: a cohort study in real-world patients. ScientificWorldJournal. 2012;2012:564706.

30. Brunello F, Veltri A, Carucci P, Pagano E, Ciccone G, Moretto P, et al. Radiofrequency ablation versus ethanol injection for early hepatocellular carcinoma: a randomized controlled trial. Scand J Gastroenterol. 2008:43:727-35.

31. Giorgio A, Di Sarno A, De Stefano G, Scognamiglio U, Farella N, Mariniello A, et al. Percutaneous radiofrequency ablation of hepatocellular carcinoma compared to percutaneous ethanol injection in treatment of cirrhotic patients: an Italian randomized controlled trial. Anticancer Res. 2011;31:2291-5.

32. Forner A, Bruix J. Ablation for hepatocellular carcinoma: is there need to have a winning technique? J Hepatol. 2010;52:310-2.

33. Livraghi T, Goldberg SN, Lazzaroni S, Meloni F, lerace T, Solbiati L, et al. Hepatocellular carcinoma: radio-frequency ablation of medium and large lesions 1. Radiology. 2000;214:761-8.

34. Higgins J, Green S. Cochrane handbook for systematic reviews of interventions version 5.0. 2 [updated September 2009]. The Cochrane Collaboration 2009. 2010.

35. Parmar MKB. Extracting summary statistics to perform meta-analyses of the published literature for survival endpoints. Stat Med. 1998;17:2815-34.

36. Tierney JF, Stewart LA, Ghersi D, Burdett S, Sydes MR. Practical methods for incorporating summary time-to-event data into meta-analysis. Trials. 2007;8:16.

37. Begg CB, Mazumdar M. Operating characteristics of a rank correlation test for publication bias. Biometrics. 1994;50:1088-101.

38. Egger M, Smith GD, Schneider M, Minder C. Bias in meta-analysis detected by a simple, graphical test. BMJ. 1997;315:629-34.

39. Azab M, Zaki S, El-Shetey AG, Abdel-Moty MF, Alnoomani NM, Gomaa AA, et al. Radiofrequency ablation combined with percutaneous ethanol injection in patients with hepatocellular carcinoma. Arab J Gastroenterol. 2011;12:113-8.

40. Lencioni RA, Allgaier HP, Cioni D, Olschewski M, Deibert $\mathrm{P}$, Crocetti $\mathrm{L}$, et al. Small hepatocellular carcinoma in cirrhosis: randomized comparison of radio-frequency thermal ablation versus percutaneous ethanol injection 1. Radiology. 2003;228:235-40.

41. Orlando A, Leandro G, Olivo M, Andriulli A, Cottone M. Radiofrequency thermal ablation vs. percutaneous ethanol injection for small hepatocellular carcinoma in cirrhosis: meta-analysis of randomized controlled trials. Am J Gastroenterol. 2009;104:514-24.

42. Salhab M, Canelo R. An overview of evidence-based management of hepatocellular carcinoma: a meta-analysis. J Cancer Res Ther. 2011;7:463-75.

43. Shen A, Zhang H, Tang C, Chen Y, Wang Y, Zhang C, et al. Systematic review of radiofrequency ablation versus percutaneous ethanol injection for small hepatocellular carcinoma up to $3 \mathrm{~cm}$. J Gastroenterol Hepatol. 2013;28:793-800

44. Germani G, Pleguezuelo M, Gurusamy K, Meyer T, Isgro G, Burroughs AK. Clinical outcomes of radiofrequency ablation, percutaneous alcohol and acetic acid injection for hepatocelullar carcinoma: a meta-analysis. J Hepatol. 2010:52:380-8

45. Weis S, Franke A, Mössner J, Jakobsen JC, Schoppmeyer K. Radiofrequency (thermal) ablation versus no intervention or other interventions for hepatocellular carcinoma. Cochrane Database Syst Rev. 2013;12:CD003046.

46. Dong W, Zhang T, Wang ZG, Liu H. Clinical outcome of small hepatocellular carcinoma after different treatments: a meta-analysis. World J Gastroenterol. 2014;20:10174-82.

47. Xu RH, Gao W, Wang C, Guo DK, Tang L, Zhang H, et al. Systematic evaluation of percutaneous radiofrequency ablation versus percutaneous ethanol injection for the treatment of small hepatocellular carcinoma: a meta-analysis. Eur J Med Res. 2014;19:39.

48. Lopez PM, Villanueva A, Llovet JM. Systematic review: evidence-based management of hepatocellular carcinoma-an updated analysis of randomized controlled trials. Aliment Pharmacol Ther. 2006;23:1535-47.

49. Ebara M, Okabe S, Kita K, Sugiura N, Fukuda H, Yoshikawa M, et al. Percutaneous ethanol injection for small hepatocellular carcinoma: therapeutic efficacy based on 20-year observation. J Hepatol. 2005;43:458-64.

50. Wood L, Egger M, Gluud LL, Schulz KF, Jüni P, Altman DG, et al. Empirical evidence of bias in treatment effect estimates in controlled trials with different interventions and outcomes: meta-epidemiological study. BMJ. 2008:336:601.

\section{Submit your next manuscript to BioMed Central and take full advantage of:}

- Convenient online submission

- Thorough peer review

- No space constraints or color figure charges

- Immediate publication on acceptance

- Inclusion in PubMed, CAS, Scopus and Google Scholar

- Research which is freely available for redistribution 